\title{
COM "OS NOSSOS ANCESTRAIS": LUTA E GRAMÁTICA NO RECONHECIMENTO DE LUGAR DE REMANESCENTES HUMANOS NO RIO DE JANEIRO
}

WITH “OUR ANCESTORS”: FIGHT AND GRAMMAR IN THE RECOGNITION OF PLACE OF HUMAN REMAINS IN RIO DE JANEIRO

AVEC "NOS ANCETRES": LUTTE ET GRAMMAIRE DANS LA RECONNAISSANCE DE SITES DE RESTES HUMAINS À RIO DE JANEIRO

CON “NUESTROS ANTEPASADOS”: LUCHA Y GRAMÁTICA EN EL RECONOCIMIENTO DE LUGAR DE REMANENTES HUMANOS EN RÍO DE JANEIRO

Marcia Leitão Pinheiro

RESUMO: Com a revitalização urbana na região portuária da cidade do Rio de Janeiro como parte do Projeto Porto Maravilha, iniciado em 2011, ocorreu a descoberta de sinais de um antigo cemitério de escravizados. Diante disso, organizações do movimento negro passaram a atuar para a preservação do local e também para que houvesse homenagem aos antepassados no espaço público. A partir de pesquisa qualitativa, uso de documentos e vídeos, contemplo como foi tornado corrente o uso de categorias relacionadas à investigação da verdade e promoção de reparação, para discutir a escravidão e o tráfico transatlântico. Além disso, cerimônias religiosas foram realizadas, a fim de reconhecer a energia do lugar e a força dos ancestrais, contribuindo para a composição local do debate acerca das tragédias e dores históricas.

Palavras-chave: movimento negro; antepassados; verdade; reparação; escravidão.

ABSTRACT: In 2011, the works of Porto Maravilha ("Mar-

\footnotetext{
* Doutora em Ciências Humanas (Antropologia Cultural); Professora da Universidade Estadual do Norte Fluminense Darcy Ribeiro (Uenf), Campos dos Goytacazes, RJ, Brasil; e-mail: marcialpx@hotmail.com 
velous Port") project started, as part of the urban revitalization of Rio de Janeiro's port region. By then, there were discovered signs of an ancient cemetery of enslaved people. Faced with this, black movement organizations began to work for preserving the place and for honoring the ancestors in the public space. From qualitative research and using documents and videos, I considered how truth investigation and repair promotion categories to discuss slavery and transatlantic trafficking became current. In addition, there were religious ceremonies in order to recognize the place energy and the ancestors' strength, contributing to the local composition of the debate about tragedies and historical pains.

Keywords: black movement; ancestors; truth; repairing; slavery.

$\boldsymbol{R} \boldsymbol{E} \boldsymbol{S U} \boldsymbol{M E}:$ Avec la revitalisation urbaine dans la région portuaire de la ville de Rio de Janeiro, dans le cadre du projet Porto Maravilha, lancé en 2011, on a découvert des signes d'un ancien cimetière de personnes asservies. Devant cela, les organisations du mouvement noir ont commencé à travailler pour la préservation du site archeologique et pour rendre hommage aux ancêtres dans l'espace public. A partir de recherches qualitatives, de la utilisation de documents et de vidéos, j'envisage comment l'utilisation des catégories liées à la recherche de la vérité et à la promotion de la réparation pour discuter l'esclavage et le trafic transatlantique est devenue courante. En outre, des cérémonies religieuses ont été organisées afin de reconnaître l'énergie du site et la force des ancêtres, contribuant ainsi à la composition locale du débat sur les tragédies et les douleurs historiques.

Mots-clés: mouvement noir; ancêtres; vérité; réparation; esclavage.

RESUMEN: Con la revitalización urbana en la Región Portuaria de la ciudad de Río de Janeiro como parte del Proyecto Porto Maravilha, iniciado en 2011, se descubrieron señales de un antiguo cementerio de esclavizados. Ante eso, organizaciones del movimiento negro comenzaron a actuar para la preservación del local y también para que sirviera homenaje a los antepasados en el espacio público. A partir de una investigación cualitativa, el uso de documentos y vídeos, se examina cómo se ha hecho corriente el uso de categorías relacionadas con la investigación de la verdad y la promoción de la reparación para discutir la esclavitud y el tráfico transatlántico. Además, las ceremonias religiosas se realizaron para reconocer la energía del lugar y la fuerza de los antepasados, contribuyendo a la composición 
Com "os nossos ancestrais": luta e gramática no reconhecimento de lugar de remanescentes humanos no Rio de Janeiro

local del debate acerca de las tragedias y los dolores históricas.

Palabras clave: movimiento negro; antepasados; verdad; reparación; esclavitud.

\section{COM "OS NOSSOS ANCESTRAIS": LUTA E GRAMÁTICA NO RECONHECIMENTO DE LUGAR DE REMANESCEN- TES HUMANOS NO RIO DE JANEIRO}

Desde o início das obras do Projeto Porto Maravilha, em 2011, realizado pela Prefeitura da Cidade do Rio de Janeiro e voltado à revitalização da histórica região portuária, associações do movimento negro - que defendem diferentes aspectos da questão racial - têm atuado para resguardar lugares considerados testemunhos do legado africano $^{1}$ e negro na cidade e no país. Nesse caso, encontra-se o Cais do Valongo, por sua relevância em relação à escravidão negra e ao tráfico transatlântico. Ele é considerado um "sítio histórico de memória sensível", porque materializa memórias de eventos de violação dos direitos humanos, conforme figura no dossiê de candidatura a patrimônio da humanidade (Iphan, 2016, p.142), sendo posteriormente reconhecido como tal pela Organização das Nações Unidas (Unesco).

A ação das organizações negras não visa somente ao cais, e sim a outros lugares entendidos como relevantes para o reconhecimento de um território negro - conhecido por Pequena África -, com implicações culturais e políticas para a cidade. Outra localidade teve importância acentuada para os coletivos negros, com a continuidade das obras do Projeto Porto Maravilha, especificamente, com a escavação de ruas para a instalação da linha 3 do Veículo Leve sobre Trilho (VLT) - mecanismo que integra o sistema de mobilidade urbana. Durante as obras, descobriram-se 15 esqueletos, que foram ligados com uma antiga igreja já demolida, fragmentos de ossos humanos - crânio, tíbia e dentes, por exemplo - e de objetos - pedaços de cerâmica e de porcelana ${ }^{2}$. Os ossos foram relacionados com um cemitério existente no terreno da Igreja de Santa Rita, outrora desti-

1 As palavras e as expressões referentes ao cenário pesquisado estão registradas em itálico. 2 VIEIRA, Isabela: Escavações podem revelar cemitério de escravos africanos no Rio. Disponível em: $\mathrm{http} / /$ agenciabrasil.ebc.com.br/geral/noticia/2018-07/escavacoes-podem-revelar-cemiterio-de-escravos-africanos-no-rio. Acesso em: 27 jan. 2019. 
nado ao sepultamento de africanos escravizados ${ }^{3}$ recém-chegados ao país - os chamados pretos novos.

Diante dos elementos encontrados, foi instalada uma pesquisa arqueológica da área escavada, conforme estabelece os instrumentos do Instituto do Patrimônio Histórico e Artístico Nacional (Iphan) - órgão federal dedicado à proteção e promoção do patrimônio imaterial e material do Brasil ${ }^{4}$.

Desde o início da intervenção urbana na área, as organizações do movimento negro têm discutido com diferentes atores sobre a preservação do lugar e dos remanescentes humanos. Isso ficou explícito nos vários eventos realizados, em que o Largo de Santa Rita e o tema da reparação foram centrais: a audiência pública realizada pelo Ministério Público Federal (MPF), em agosto de 2018; o seminário realizado no Arquivo Nacional sobre reparação da escravidão, em setembro de 2018; a cerimônia inter-religiosa, ocorrida no mesmo ano, que serão abordadas mais adiante.

Em geral, as mobilizações têm a ver com a explicitação da verdade sobre a escravidão e o tráfico transatlântico, pois produziram sofrimentos e vítimas entre os capturados e os escravizados. Além disso, há uma articulação com o tema da violência no passado e no presente da sociedade brasileira. Trata-se de um ponto sensível para as organizações do movimento negro, envolvidas com a exposição do sofrimento dos antepassados no espaço público. Isso, portanto, está associado com a construção de seu reconhecimento, a ser expresso em memoriais, em cerimônias e em outras medidas, como será demonstrado no decorrer deste artigo.

$\mathrm{O}$ que as organizações do movimento negro fazem e os elemen-

\footnotetext{
3 A externalização dessas antigas necrópoles não é singular, pois, em diversas cidades do Brasil e de outros países - localizados no Caribe, na América do Norte, na Europa e países africanos, por exemplo -, isso tem sido registrado (Unesco, 2019). Esses lugares têm recebido a atenção de disciplinas interessadas na diáspora africana, nas criações culturais, nas articulações entre diferentes atores para a produção de narrativas e de patrimônios afrodescendentes, como parte de suas lutas. 4 O Iphan conta com legislação sobre licenciamento ambiental, compreendendo o impacto de empreendimentos em monumentos e sítios arqueológicos, históricos e culturais. A proteção de bens arqueológicos está prevista, desde o decreto de criação do Iphan, em 1937, sendo reconhecidos como parte do patrimônio cultural nacional pela Constituição Federal de 1988. O país conta ainda com a lei que protege os bens de natureza arqueológica - Lei Federal 3.924 de 1961- e criou, em 2009, o Centro Nacional de Arqueologia (CNA), voltado à elaboração de políticas e gestão do patrimônio, além do Cadastro Nacional de Sítios Arqueológicos (CNSA), no qual devem ser registrados os sítios reconhecidos. Fonte: http://portal.iphan.gov.br/pagina/detalhes/1376/. Acesso em: fev. de 2019.
} 
Com "os nossos ancestrais": luta e gramática no reconhecimento de lugar de remanescentes humanos no Rio de Janeiro

tos por elas utilizados para demarcar a dor e o crime da escravidão não são inusitados, pois, em outros contextos, existem atores que enfatizam que suas dores e sofrimentos estariam na base de suas ações em confronto com as violências - étnica, religiosa, cultural- vividas no passado e que, mesmo assim, afetam a existência individual e coletiva das gerações posteriores (Wieviorka, 2009). Essas dores coletivas ou individuais têm demarcado o espaço político e, por sua vez, as ações institucionais que surgem e nas quais se discutem sentimentos, valores, estereótipos, práticas estatais e cidadania (Fassin, 2015; Gatti, 2017).

Governos de diversos países têm, no curso de anos, aplicado um mecanismo que se caracteriza pela promoção da verdade, da reconciliação, da reparação, da memória e da reforma das instituições, como a Comissão da Verdade (CV). Fala-se, então, em cenários de transição política, que visam a expor e confrontar as violações dos direitos humanos, a ruptura com o passado de violência e envolvem uma construção acerca do presente e do futuro (Hayner, 2006; Castillejo, 2015). As reflexões que analisam as exumações de corpos de desaparecidos vitimados por violência política explicitam as interações, as questões, as práticas, as ferramentas e os sentidos que perpassam os atores envolvidos com tal cenário (Ferrandiz, 2017; Rousseau, 2017). Outro ponto a ser destacado tem a ver com os temas, as linguagens e as categorias que são mobilizados localmente e favorecem a reinterpretação da sociedade e modos de articular e enfrentar o passado de violações (Castillejo, 2013).

Este artigo contempla a apropriação e a aplicação de elementos pertinentes ao cenário da $\mathrm{CV}$ por organizações do movimento negro no Brasil. Busco refletir como os vestígios de remanescentes humanos fomentaram a atuação dessas organizações civis e quais elementos elas relacionaram. Focalizarei os eventos e as cerimônias nos quais a presença de componentes religiosos possibilitou a inscrição de específicas categorias, que foram articuladas com a gramática de esclarecimento histórico. Será visto ainda como a presença religiosa viabilizou a criação de espaço e modos de reconhecimento do lugar e dos remanescentes de corpos humanos encontrados, que foram alçados à condição de vítima.

Para a elaboração deste artigo, além das anotações pro- 
venientes de observação direta das atividades já citadas, recorro a um vídeo produzido por agremiação cultural, outro produzido pelo Instituto do Patrimônio Histórico e Artístico Nacional (Iphan), a documentos elaborados pela Prefeitura da Cidade do Rio de Janeiro, pela Companhia de Desenvolvimento Urbano da Região do Porto do Rio de Janeiro (Cdurp), gestora da prefeitura na Operação Urbana Consorciada Porto Maravilha, disponibilizados em site e blog, e matérias disponíveis em sites jornalísticos.

A organização do artigo compreende, além da introdução, mais cinco partes. Na primeira, faço a exposição sobre o dispositivo de investigação da verdade e o tema da reparação, ressaltando como são inscritos no cenário pesquisado. Na segunda parte, explicito como a revitalização da região portuária tem sido um espaço de atuação das organizações do movimento negro. Na terceira, descrevo como o Largo da Igreja de Santa Rita guarda especificidades da história da cidade e da área do porto. Na quarta, apresento uma descrição das atividades nas quais a igreja e os remanescentes humanos foram parte da discussão acerca da revitalização urbana. Na conclusão, reflito sobre a tensão no tocante a preservação dos remanescentes humanos, assim como a contribuição da dimensão religiosa para a mobilização conduzida por associações do movimento negro.

\section{ESCLARECIMENTO HISTÓRICO}

A vigência do mecanismo de apuração da verdade ocorre desde os anos 1980, tendo por característica a busca por esclarecimento histórico de tragédias políticas. Mais conhecido por Comissão da Verdade (CV), tem sido dito que esse dispositivo se volta à promoção de pacificação política e a explicitar as conexões que sustentam as desigualdades. Ele também tem sido relevante para o estabelecimento de políticas de memória e compensações individuais e coletivas, perfazendo a dimensão da reparação. Isso pode também incluir a investigação de covas coletivas e/ou clandestinas, as exumações de corpos e a realização de sepultamentos dignos (Cuya, 2011; Castillejo, 2015; Ferrandiz, 2017; Rousseau, 2017). Em geral, o tema do conflito e da violência política têm sido mobilizado por grupos que 
Com "os nossos ancestrais": luta e gramática no reconhecimento de lugar de remanescentes humanos no Rio de Janeiro

se apresentam como vítimas e têm, ao longo do tempo, exposto no espaço público seus pleitos por constatação de suas dores e traumas. Trata-se de formação de espaço e de personagem, cujo reconhecimento e atendimento a suas demandas exigem mecanismos institucionais, sentimentos e moralidades, que perpassam a burocracia estatal (Fassin, 2015; Gatti, 2017).

Apesar de sua mundialização, esse mecanismo de promoção da verdade e reparação termina por ter também características locais. No caso do Brasil, sua aplicação corroborou uma atmosfera de confronto histórico do regime ditadorial, com a instalação da Comissão Nacional da Verdade (CNV), criada, em 2011, pelo Executivo Nacional. Ela visou a apurar as práticas violentas do Estado nacional, entre 1946 e 1988, conforme estabelece a Lei 12.528/11, que contempla os locais, as estruturas e as instituições envolvidas com as violações dos direitos humanos ${ }^{5}$.

No país também foi criada, em 2014, a Comissão Nacional da Verdade da Escravidão Negra no Brasil (Cvenb), sem ligação com a instância governamental, mas com o apoio da Ordem dos Advogados do Brasil (OAB), entidade de representação profissional, fundada em 1930. A Cvenb segue fundamentos legais no tocante à violação dos direitos humanos, que prima pela promoção da verdade e da memória, reparações e reformas institucionais (Santos, 2018). Ela conta com a participação de organizações do movimento negro e de especialistas em direito, educação, ciências sociais e outras áreas do conhecimento, apresenta congêneres em diversos estados e municípios. O objetivo é questionar o passado de rebaixamento humano à condição de mercadoria, explicitar a ligação entre a violência e os crimes que configuraram o tráfico transatlâtico de africanos e a escravidão. Essa comissão, conduzida por organizações civis, também busca afirmar a ligação entre o passado e o presente, diante das violências que, ainda hoje, vitimizam a população negra no país, seja com o desemprego, com os ataques às religiões de matrizes africanas, ou com os desaparecimentos, mortes e encarceramentos (Pinheiro, 2018 a, b). Sobre o assunto, o relatório parcial da Comissão

5 Convém explicitar que a denúncia da repressão política já era elemento de mobilização na sociedade brasileira desde os anos de 1970, com iniciativas não estatais, resultando em documentos sobre desaparecimentos e mortes de civis. 


\title{
Estadual da Verdade da Escravidão Negra no Brasil ${ }^{6}$ - Cvenb (OAB/ RJ, 2015, p.162) coloca o seguinte:
}

\begin{abstract}
A tragédia da escravidão amolda-se em tudo e por tudo ao crime de genocídio e ao crime contra a humanidade. Crimes imprescritíveis. É mérito deste Relatório evitar que perdure o silêncio sobre essas barbáries de tal magnitude. Este silêncio quanto ao passado faz alcançar na linha do tempo um silêncio também de cumplicidade com as consequências que esse passado legou ao presente.
\end{abstract}

É corrente entre as organizações negras que integram o cenário de promoção da verdade da escravidão a defesa de outra memória capaz de questionar o silêncio e/ou as construções históricas sobre a escravidão, apresentada como cordial ou o escravizado visto somente como rebelde. Desse modo, há a perspectiva de demarcar a escravidão como fenômeno de incomensurável prejuízo para a humanidade e, para tanto, ocorre a busca de provas dos crimes cometidos contra os escravizados (Pinheiro, 2018 a).

Além da verdade, a reparação é outra dimensão de luta de coletividades e indivíduos, que buscam alguma compensação por aquilo que tenha afetado suas existências. Isso ocorre também em países com população negra, cujo terreno deve contar com os movimentos abolicionistas latino-americanos, a revolução haitiana e também o movimento por reparação defendido por organizações negras norte-americanas, isso, desde a década de 1960. Nesse caso, sua presença integra o que tem sido chamado de movimento por afrorreparação e está ligado às organizações contra a "opressão racial"

6 Relaciono alguns integrantes que cooperam com a Cvenb do estado do Rio de Janeiro, que tenho pesquisado desde o ano de 2015: Quilombo Raça e Classe, Confederação Nacional Quilombola (Conaq), Agentes da Pastoral Negra (APNs), Movimento Negro Unificado (MNU), União de negros e negras pela Igualdade (Unegro), Centro de Tradições Afro-Brasileiras (Cetrab), Associação das Comunidades Quilombolas do Rio de Janeiro (Acquilerj), Instituto Pretos Novos (IPN), Conselho Municipal de Defesa dos Direitos do Negro (Comdedine), Renascença Clube, Sindicato dos Metroviários do Estado do Rio de Janeiro (Simerj), Agbara Dudu, Movimento Afro-Brasileiro de Cultura de Teresópolis (Mocabte), Associação Quilombola da Rasa, Superintendência de Políticas de Promoção da Igualdade Racial de São João de Meriti (Suppir-Meriti), Comissão da Igualdade Racial (OAB/RJ), Ordem dos Advogados do Brasil de Magé, Comissão da Igualdade Racial da $\mathrm{OAB} /$ Cabo Frio), Núcleo contra a Desigualdade Racial da Defensoria Pública (Nucora), Instituto Federal do Rio de Janeiro de Paulo de Frontin, Faculdades Paraíso /Grupo Lusófono e Viva Rio. Eles têm relação com a defesa da educação superior inclusiva, com o reconhecimento da religiosidade e das tradições afro-brasileiras, com a defesa de direitos territoriais, com a produção de pesquisas pertinentes às condições de vida da população negra; há ainda sindicatos, núcleos e superintendências ligadas ao Executivo de algum município ou órgão de classe, com envolvimento com a promoção da igualdade racial e o combate ao racismo. 
e a obtenção de "justiça racial". Isso não está relacionado somente com o passado de escravidão, seja quando focaliza a África - com movimentos voltados à valorização das culturas e histórias africanas e o cancelamento das dívidas dos países africanos -, seja quando se fala na indenização da população negra dos países americanos. Acrescenta-se, ainda, a promoção de uma memória da escravidão, a descolonização do imaginário, a criação de arquivos sobre a opressão racial, o posicionamento contra as desigualdades que impactam a vida dos afro-descendentes, assim como o futuro de emancipação da opressão e da injutiça raciais. Nas Américas, as mobilizações por afrorreparação estão associadas com a redistribuição de riqueza e de poder político, bem como com o reconhecimento dos valores e das culturas produzidas pelas populações negras. Nesse caso, busca-se o alcance de uma cidadania não subalterna, e sim plena, ou seja, com a obtenção da "cidadania social, civil, política, economica y cultural" (Lao-Montes, 2007, p. 138; 2009).

Como se pode compreender, além da verdade, o tema da reparação é amplo e diverso, porque cada localidade apresenta sua demanda e como ela deve ser compensada. No Brasil, a exigência de reparação está presente entre os afro-brasileiros - em reuniões, seminários, festas religiosas, por exemplo -, e marca iniciativas. Em 2001, o grupo Afro-Liberal, do Rio de Janeiro, ligado ao então prefeito Cesar Maia (na época pelo Partido Trabalhista Brasileiro - PTB), enviou uma petição à Organização dos Estados Americanos (OEA), exigindo reparação para o crime de escravidão ocorrido no Brasil ${ }^{7}$.

Envolvido com o tema, Yedo Ferreira, um dos fundadores do Instituto de Pesquisa das Culturas Negras (IPCN), surgido em 1975, e do Movimento Negro Unificado (MNU), criado em 1978, lançou, em 2010, uma cartilha sobre o tema. Em entrevista para um projeto desenvolvido no Centro de Pesquisa e Documentação de História Contemporânea do Brasil (Cpdoc), da Fundação Getúlio Vargas, Ferreira (2007) observou que a internacionalização do tema ocorreu com a Conferência de Durban, realizada em 2001, com países africanos e caribenhos, que passaram a pleitear "reparação pelo co- 
lonialismo, pelo escravismo e pelo tráfico transatlântico" (Alberti; Pereira, 2007, p. 414) ${ }^{8}$.

As comissões que relacionam a apuração da verdade, reparação e escravidão têm debatido como o Estado brasileiro se beneficiou da prática comercial, baseada no tráfico e na submissão de africanos, considerados uma tragédia e entendidos como crime imprescritivel. Contudo, a discussão resulta em definir que o dano causado não está restrito aos atos passados, pois eles ainda atingem a geração contemporânea, através das exclusões e desigualdades. A discussão sobre o dano de longo alcance tem implicação específica, pois se deve apurar a responsabilidade estatal acerca do crime da escravidão, conforme relatório parcial da Cvenb (OAB/RJ, 2015). De acordo com Ferreira (2007), o conceito de reparação é relevante para a ação política, porque possibilita relacionar passado e presente, quando se trata de apurar e responsabilizar as violações sofridas. No entanto, cada país definiria o que seria essa reparação e, no caso do Brasil, esse trabalho ainda deve ser conduzido (Alberti; Pereira, 2007).

Os elementos de esclarecimento de tragédias e dores históricas, seu gerenciamento, envolvendo o tema da reparação, aparecem em diversos atos realizados no Cais do Valongo. Tais elementos também tiveram forte presença com a emergência dos sinais de um antigo lugar de enterramento de corpos de escravizados, que cooperou para estimular o debate e as ações das organizações do movimento negro, possibilitando jogar luz sobre o tema da reparação da tragédia e do sofrimento - e ainda ressaltar a relevância da localidade para a história da cidade e do país.

\section{REGIÃO PORTUÁRIA E SUA ESPECIFICIDADE}

A região portuária da cidade do Rio de Janeiro constitui parte do centro antigo da cidade e reconhecida como histórica, somente na

8 No Brasil, além da Conferência de Durban, ocorrida em 2001, são citadas outras duas iniciativas. O Projeto Rota do Escravo, criado há mais de 20 anos pela Unesco, que visa a valorizar os lugares que expressam mais a memória e a agência do escravizado e menos a herança colonial (Mattos; Abreu; Guran, 2014). A Década Internacional do Afrodescendente (2015-2025), proclamada pela Assembléia Geral da ONU, volta-se à promoção do respeito e proteção dos direitos humanos dos afrodescendentes, assim como do patrimônio, da cultura e da contribuição da população afrodescendentes para as sociedades. 
Com "os nossos ancestrais": luta e gramática no reconhecimento de lugar de remanescentes humanos no Rio de Janeiro

década de 1980 (Guimarães, 2014). Nela, está localizada a Igreja de Santa Rita, cujo largo tem mobilizado a atenção das organizações do movimento negro, de religiosos e de pesquisadores, sobretudo com a condução de uma revitalização urbana, como será demonstrado.

O centro histórico relacionado com a atividade portuária tem sido alterado com o Projeto Porto Maravilha, uma iniciativa público-privada, com obras executadas pelo Consórcio Porto Novo ${ }^{9}$ e administradas pela Companhia de Desenvolvimento Urbano da Região do Porto do Rio de Janeiro (Cdurp). A operação consorciada urbana, com início em 2011, com custo de oito bilhões de reais, atinge uma área de cinco milhões de $\mathrm{m}^{2}$ e tem resultado no desaparecimento de prédios e logradouros, no aparecimento de novas edificações, na restauração e conservação de alguns imóveis, no estabelecimento de hotéis, empresas e lugares para eventos.

O projeto de revitalização suscitou posicionamentos críticos, sobretudo por parte de setores da sociedade que apontaram as intervenções nas áreas públicas, os modos de violência e de sua condução, especificamente, a expulsão de moradores. Além disso, houve a acusação de tratamento diferenciado dado aos locais ligados à população negra, diante dos recursos aplicados na construção do Museu do Amanhã, na Praça Mauá, e o que foi direcionado ao patrimônio e aos espaços de representação afro-brasileira.

Durante as obras, em 2011, o Cais do Valongo foi desenterra$\mathrm{do}^{10} \mathrm{e}$, diante dos sinais de suas ruínas, houve a atuação de organizações do movimento negro, situadas ou não na região portuária ${ }^{11}$, e de órgãos estatais ${ }^{12}$, com a finalidade de assegurar a preservação do

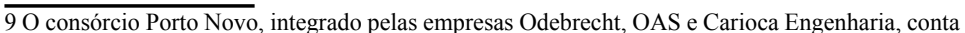
com incentivos dos governos federal e estadual para as obras de requalificação urbana.

10 Ele teria surgido nos primeiros anos de 1800 e ficou em atividade até 1831 , mas foi aterrado em 1843, para o desembarque da futura imperatriz, e novamente coberto em 1903, com a reforma urbana realizada por Pereira Passos.

11 Instituto de Pesquisa das Culturas Negras (IPCN), fundado, em 1984, no Rio de Janeiro, União de Negros pela Igualdade (Unegro), fundada, em 1888, em Salvador e presente em diversos estados do país, Quilombo da Pedra do Sal (Arquipedra), localizado na região portuária, Centro de Articulação de Populações Marginalizadas (Ceap), surgida no Rio de Janeiro, Incubadora Afro Brasileira, surgida no Rio de Janeiro, no início dos anos 2000, e voltada à formação de empreendedores afro-brasileiros, Afro Brasil Turismo, entre outras.

12 A Fundação Cultural Palmares, a Superintendência de Promoção da Igualdade Racial (Supir), a Coordenadoria Especial de Promoção das Políticas de Igualdade Racial (Ceppir), o Conselho Estadual dos Direitos do Negro (Cedine) e o Conselho Municipal de Defesa dos Direitos do Negro (Comdedine). Esses órgãos contam com a participação de coletivos do movimento negro, para o combate ao racismo e à discriminação racial, bem como o assessoramento de projetos, programas e propostas voltados à população negra. 
atracadouro e reivindicar a construção de um memorial da diáspora africana no local. O Conselho Municipal de Defesa dos Direitos do Negro da Cidade do Rio de Janeiro (Comdedine) ${ }^{13}$ corroborou o diálogo entre a prefeitura e as organizações negras que atuavam em prol dos lugares de memória afro-brasileira. Como resultado da ação, em 2011, foi promulgado pela Prefeitura da Cidade do Rio de Janeiro (PCRJ) o Decreto Municipal 34.803, que instituiu o Circuito Histórico e Arqueológico de Celebração da Herança Africana e o Grupo de Trabalho Curatorial do Projeto Urbanístico, Arquitetônico e Museológico ${ }^{14}$ do circuito.

O Circuito da Celebração Africana conta com seis lugares, sendo eles: Pedra do Sal, local onde os escravos faziam o descarregamento de mercadoria; Jardim Suspenso do Valongo, construído nos primeiros anos da República com a utilização de artefatos retirados do Cais da Imperatriz; Largo do Depósito, destinado à guarda dos africanos desembarcados; o Instituto Pretos Novos (IPN), localizado na área do Cemitério dos Pretos Novos (CPN), voltado ao sepultamento dos africanos mortos antes de sua negociação; e perto do IPN, está o Centro Cultural José Bonifácio, edificação construída durante o Império e onde funciona, desde 1994, o Centro de Referência da Cultura Afro-Brasileira e o Museu da História e da Cultura Afro-Brasileira (Muhcab) - criado em 2017.

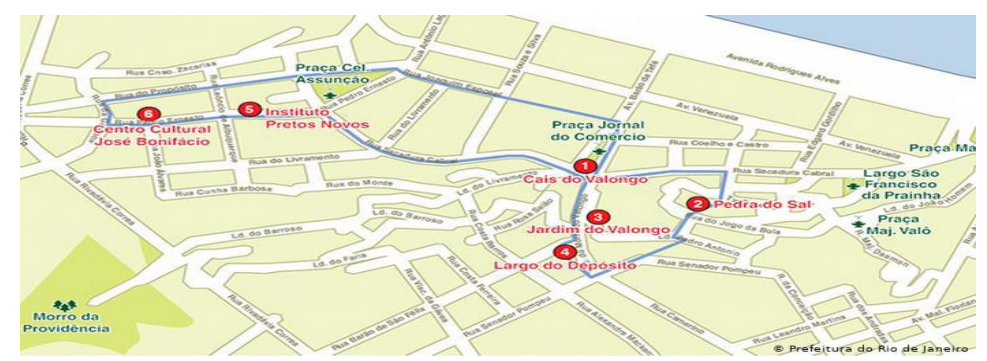

Prefeitura da Cidade do Rio de Janeiro

Alguns locais da região portuária são considerados fundamentais para pesquisadores e organizações do movimento negro, 
por estarem relacionados com a história e com a memória da escravidão e de períodos posteriores - sobretudo aquelas implicadas na afirmação de um território negro chamado de Pequena África, que abrange alguns locais da região portuária. Essa relevância também é destacada por sacerdotisas das religiões afro-brasileiras, que, convidadas pela prefeitura da cidade, apontaram para os locais sagrados, isto é, possuidores de força espiritual, que integram o Circuito da Celebração Africana, tais como: a Pedra do Sal, o Cais do Valongo, eleito Patrimônio da Humanidade, em 2017, e o Cemitério dos Pretos Novos - onde hoje está o Instituto de Pesquisa e Memória Pretos Novos (IPN) ${ }^{15}$ (Carneiro; Pinheiro, 2015). Esse cemitério funcionou de 1792 a 1830, sendo descoberto em 1996, durante a realização de reforma de uma residência, quando se encontraram remanescentes humanos. Soma-se agora o Largo de Santa Rita, que compreende a igreja e sua área frontal.

\section{LARGO DE SANTA RITA}

O Largo de Santa Rita fica vizinho à principal via de comunicação da cidade, a avenida Presidente Vargas, aberta em 1940, e do Colégio Pedro II, criado em 1837, que integra a rede federal de ensino. No largo, está localizado o templo, erguido antes de 1721, pela família portuguesa Nascentes Pinto, que ocupava uma chácara na localidade.

A família trouxe de Porto (Portugal) para o Brasil a devoção à Santa Rita, conhecida como a padroeira das causas impossíveis, beatificada na Itália e cujo culto se espalhou por países vizinhos. O templo, que ainda conserva o rococó do século XVIII como característica arquitetônica, foi doado pela família à irmandade de Santa Rita. Essa igreja teve lugar importante na empreitada escravista, já que esteve relacionada com o enterramento de corpos de africanos traficados para o país. Antes disso, no curso do século XVII, os sepultamentos de escravizados, indigentes e indígenas aconteciam numa área localizada junto ao morro do Castelo e vizinho da Santa

15 Trata-se de uma entidade civil, criada em 2005, voltada à pesquisa, estudo e preservação do patrimônio material e imaterial afro-brasileiro. 
Casa da Misericórdia. Já no século XVIII, o local ficou saturado, sobretudo em decorrência do tráfico de escravizados, resultando na determinação do governador em constituir um cemitério em outra localidade (Nara Jr., 2015).

Então, por volta dos anos 20 do século XVIII, o governador do Rio de Janeiro, Ayres Saldanha, determinou que, na parte frontal da Igreja de Santa Rita, fosse instalado um cemitério, sendo reconhecido como campo santo, conforme acontecia com todo cemitério sob administração eclesiástica. Ele foi dedicado aos africanos recém-chegados que faleciam no mercado, que ficava nas imediações, e eram sepultados no terreno da igreja - espaço destinado para os menos afortunados e sem prestígio na hierarquia social da época em covas coletivas, quase insepultos, sem referencial das culturas e das tradições dos falecidos. Como costume da época, o interior dos templos era destinado ao enterro daqueles com mais alta posição social, caracterizando a específica relação entre vivos e mortos, perpassada por sensibilidades, atitudes e concepções, definindo o tratamento e o lugar de sepultamento (Rodrigues, 1997; Pereira, 2007; Nara Jr., 2014).

Posteriormente, por volta de 1769 , o marquês do Lavradio ordenou a mudança do mercado de escravizados da rua Direita (onde hoje está localizada a rua Primeiro de Março), perto da Praça XV, para a rua do Valongo (atual rua Camerino) e, desse modo, o cemitério foi junto (Rodrigues, 1997; Honorato, 2008; Nara Jr, 2015).

https://reficio.cc/publicacoes/memorias-para-servir-a-historia-do-reino-do-brasil/ largo-de-santa-rita/

No entanto, a igreja, que ficava próximo à cadeia do Aljube e da forca, permaneceu. Era o lugar onde os condenados à morte recebiam alguma "consolação" e terminou por ser relacionada com os chamados "malfeitores". Ela ainda passou a ser um ponto de aglomeração de escravizados, conforme registrou o pintor Eduard Hildebrandt, no final da primeira metade do século XIX, época na qual o cemitério já havia desaparecido e constava um chafariz. O pintor não deixou de retratar a centralidade do templo para o cotidiano negro e suas formas de sociabilidade, fosse por causa da água, fosse por causa da Festa do Divino que 
Com "os nossos ancestrais": luta e gramática no reconhecimento de lugar de remanescentes humanos no Rio de Janeiro

ocorria em sua proximidade (Pereira, 2007, p.70; Nara Jr., 2014, p. 4).

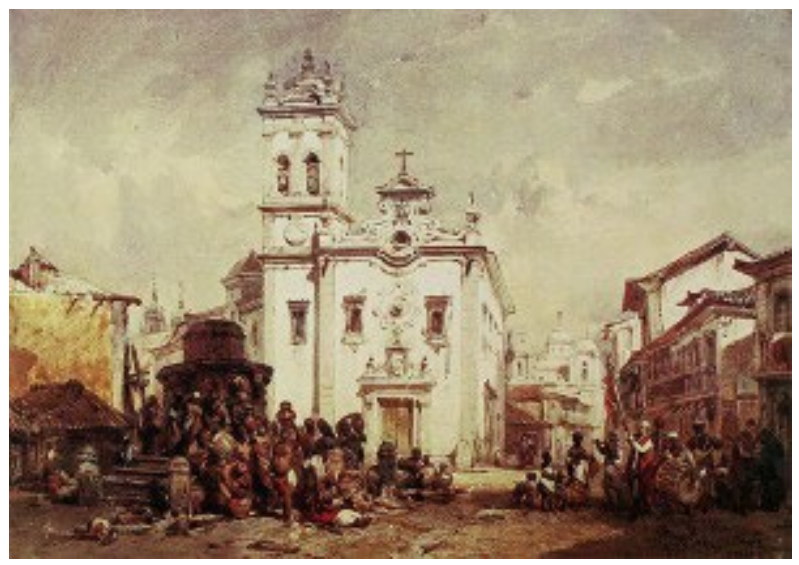

Eduard Hildebrandt - Igreja de Santa Rita (1844)

https://santarita.hypotheses.org/historia

No Valongo, o Cemitério dos Pretos Novos, que continuou sob a responsabilidade da irmandade de Santa Rita, funcionou de 1792 a 1830, considerando o povoamento da localidade e a assinatura da lei que extinguia o tráfico internacional de escravizados. Cabe explicitar que o cemitério e as demais instalações ligadas com a escravização cooperaram para a ocupação comercial e habitacional da localidade e, com o tempo, ocorreram numerosas manifestações para a sua retirada para outro lugar, devido à implicação em termos de saúde pública (Pereira, 2007; Honorato, 2008).

Com a continuidade das obras do VLT, foram encontrados, em 2018, no Largo de Santa Rita e no trecho em frente ao Colégio Pedro II, resquícios de chácaras, de mercado de venda de escravizados, de uma igreja e também esqueletos e fragmentos ósseos humanos. A área onde os esqueletos foram encontrados está no trecho do Colégio Pedro II, que era vizinho da Igreja de São Joaquim, que tinha sepultamento de fiéis em seu interior e foi demolida por uma reforma urbana realizada por Pereira Passos, no começo do século XX. Já os fragmentos ósseos - maxilar, mandíbula, falange, tíbia, vértebra, crânio e dentes - foram associados ao extinto cemitério de 


\section{Santa Rita.}

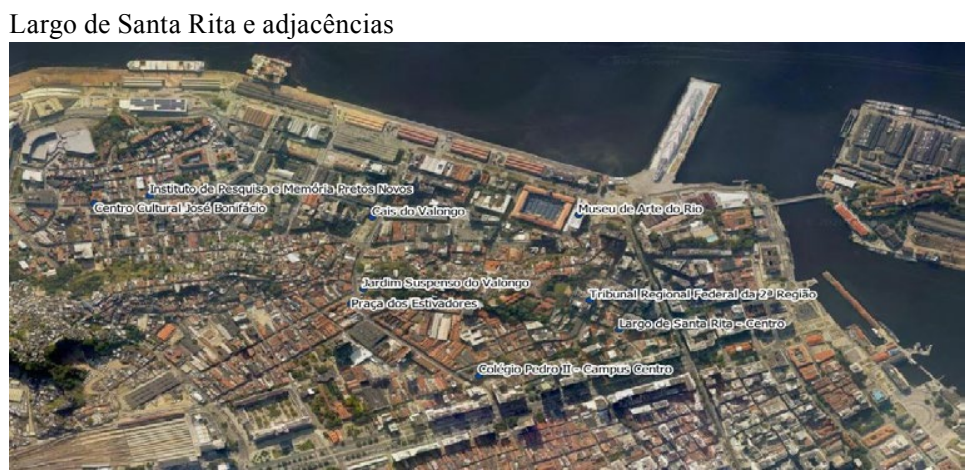

Elaboração Paulo da Silva Santos com o auxílio do Google Maps

Desde a externalização do material ósseo, aconteceram reuniões entre a empresa Artefato Arqueologia e Patrimônio, voltada à consultoria, licenciamento ambiental, pesquisa arqueológica e educação patrimonial, responsável pela pesquisa arqueológica na área de instalação do VLT, a Companhia de Desenvolvimento Urbano da Região do Porto do Rio de Janeiro (Cdurp), gestora da prefeitura na Operação Urbana Consorciada Porto Maravilha, o Instituto do Patrimônio Histórico e Artístico Nacional (Iphan) e as organizações negras. Estas têm se mobilizado para resguardar o local, afirmando-o como espaço de ancestralidade e explicitação da escravidão como crime contra a humanidade. Para tanto, elas aplicam as categorias verdade e reparação e buscam ainda informar à sociedade sobre a localização do antigo cemitério, bem como o tratamento dado aos ossos e aos objetos encontrados.

\section{DISCUTIR A REVITALIZAÇÃO, O LUGAR DE ENTERRA- MENTO E OS ANCESTRAIS}

Em 2018, o Ministério Público Federal (MPF) realizou a audiência pública, intitulada "Cais do Valongo: patrimônio cultural da humanidade: o que foi feito?”, a fim de debater as políticas públi- 
Com "os nossos ancestrais": luta e gramática no reconhecimento de lugar de remanescentes humanos no Rio de Janeiro

cas para esse sítio arqueológico.

A atividade contou com a participação de associações do movimento negro e integrantes de órgãos do governo federal, do estadual e do municipal ${ }^{16}$. Durante sua realização, ficou evidente o conflito relacionado com a ampliação das obras da terceira etapa de instalação da linha do VLT - rede de veículos que deveria atender a diversos pontos do centro da cidade do Rio de Janeiro ${ }^{17}$-, que atingiu a área da Igreja de Santa Rita. O encontro dos sinais de um antigo cemitério terminou por ser tratado em uma atividade exclusiva, num seminário ocorrido no Arquivo Nacional, órgão, fundado em 1838, voltado à gestão, preservação e difusão de documentos relacionados com a esfera federal. Além disso, ocorreu uma cerimônia religiosa dedicada aos ancestrais escravizados e sepultados na localidade. Esses três momentos serão aqui abordados.

Na audiência pública, ocorreu a leitura de uma carta endereçada ao ministro de Estado da Cultura por uma integrante da Comissão Pequena África, formada por associações negras existentes na região portuária, outras com projeção nacional e por órgãos estatais ${ }^{18}$. O texto colocou diversas exigências relacionadas às obras do VLT e afirmou a necessidade de se discutirem as intervenções no território, sobretudo no entorno da Igreja de Santa Rita, por sua implicação no sistema escravista. Nesse caso, ganhou vulto a reclamação de diálogo entre as organizações do movimento negro e as instâncias governamentais envolvidas com a revitalização na região portuária.

A carta também afirmou a necessidade de entendimento da escravidão como crime contra a humanidade e que a área fosse elevada à condição de "sítio de memória sensível" - que diz sobre o

16 Além dos procuradores federais, os seguintes órgãos estavam presentes: Ministério da Cultura, Instituto do Patrimônio Histórico e Artístico Nacional (Iphan), Fundação Cultural Palmares (FCP), Instituto Rio Patrimônio da Humanidade (IRPH), Secretaria de Cultura do Município, Conselho Municipal dos Direitos do Negro (Comdedine) e Conselho Estadual dos Direitos do Negro (Cedine).

17 A linha 3 do VLT ligará o Aeroporto Santos Dumont à Central do Brasil - onde existe um terminal de trens que conecta o centro da cidade à Baixada Fluminense.

18 A Comissão Pequena África é integrada por organizações do movimento negro voltadas à preservação de um território negro, que inclui vários lugares da região portuária, inicialmente ocupado, no século XIX, por africanos oriundos da Bahia e de negros brasileiros. Essa comissão conta com a participação das seguintes associações: Comunidade Remanescentes de Tia Ciata, Quilombo Pedra do Sal, Instituto Pretos Novos (IPN) - localizadas na região portuária -, Movimento Negro Unificado (MNU), Centro de Articulação das Populações Marginalizadas (Ceap), Instituto de Pesquisas e Estudos Afro-Brasileiros (Ipeafro), Conselho Estadual dos Direitos do Negro (Cedine), entre outros. 
lugar testemunho de tragédias históricas -, sendo, portanto, equiparada ao Cais do Valongo, bem como aos campos de concentração de Auschwitz, Birkenau e ainda à cidade de Hiroshima. Relacionado a isso, a carta enfatizou: a necessidade de reparação associada com o explicitar a verdade histórica acerca da escravidão, demarcar o protagonismo do africano escravizado e descendentes na construção do país, assim como de sua história e cultura; que as estações do VLT façam referência à história da população negra e, em seu piso, indiquem a localização dos remanescentes humanos; que os nomes das estações do VLT tenham a contribuição da população negra. Ela ainda colocou a exigência da criação de um monumento referido à justiça, na figura de um ancestral de matriz africana.

Luiz Eduardo Negrogun, presidente do Cedine - órgão estadual, fundado em 2001, que conta com a participação de coletivos negros -, que também integra a Comissão Pequena África -, observou, durante o evento, a necessidade da "ressignificação de nossos espaços, o respeito a nossa memória", e isso deveria incluir diversos locais que são referências negras. Para ele, a região portuária guarda algo específico: a força de Xangô, o orixá da justiça, pois, disse, "aquela pedra dali, a pedra do sal, foi o primeiro Xangô assentado no Rio de Janeiro por mãe Aninha ${ }^{19}$ e por nossos antepassados".

No encerramento da audiência, os procuradores apresentaram o encaminhamento para ser constituído um "fórum permanente do Valongo", integrado por organizações do movimento negro, incluindo aquelas que atuam na chamada Pequena África, membros da Prefeitura, do Instituto do Patrimônio Histórico e Artístico Nacional (Iphan), do Ministério Público Federal e da Fundação Palmares, órgão federal de promoção e preservação da contribuição negra para a formação da

19 A região do porto do Rio de Janeiro figura na literatura como central para as redes de sociabilidade formadas por baianos e africanos, sobretudo com base religiosa, com a presença e ação de sacerdotisas e sacerdotes das religiões afro-brasileiras. Nesse caso, mãe Aninha, ou Obá Biyi, é uma referência no cenário religioso afro-brasileiro. Ela era integrante do terreiro Ilê Iya Nassô, ou Casa Branca do Engenho Velho, fundado por volta de 1830, em Salvador, onde ficou até 1894/95. Depois, fundou o Axé Opô Afonjá, em 1910. Antes disso, mãe Aninha teria vindo ao Rio de Janeiro, em 1886, em companhia de Rodolfo de Andrade, Bamboxê, e Joaquim Vieira, Obá Saniá - ambos africanos. Em tal visita, a sacerdotisa teria fundado uma casa e/ou encontrado um assentamento de Xangô na Pedra do Sal, que foi por ela cuidado. Também teria realizado iniciações de membros religiosos. Já na década de 1920, mãe Aninha consolidou o Axé Opô Afonjá, no Rio de Janeiro, que passou por diversas localidades, indo da região portuária até a Baixada Fluminense (Pessoa de Barros, 2000; Conduru, 2010). 
Com "os nossos ancestrais": luta e gramática no reconhecimento de lugar de remanescentes humanos no Rio de Janeiro

sociedade brasileira, surgido em $1988^{20}$. Por fim, uma ekedi - zeladora das roupas e objetos de orixás -, referência para as organizações negras da região portuária, finalizou o encontro, fazendo uma saudação aos antepassados e às entidades de justiça da tradição afro-brasileira.

No mesmo ano, ocorreu, no Arquivo Nacional, um seminário sobre o sítio de Santa Rita, iniciativa do Instituto de Pesquisas e Estudos Afro-Brasileiros (Ipeafro), uma entidade civil, fundada, em 1981, por Abdias do Nascimento - político e intelectual negro - e que tem por diretora presidente Elisa Larkin, viúva de Abdias do Nascimento. O seminário contou com a parceria de diversas organizações do mvimento negro, e sua abertura foi marcada pela exibição de filmes sobre a diáspora global, sobre o Valongo e o legado africano, e o último sobre a visita do rei Ashanti de Gana ao Rio de Janeiro. Além disso, três jovens apresentaram a performance de "Padê de Exú Libertador", poema escrito por Abdias do Nascimento. A obra constitui uma oferenda a Exú, orixá da comunicação entre os homens, e os demais orixás, bem como da libertação. No poema, ainda são exaltados aqueles considerados referências para a libertação dos escravizados.

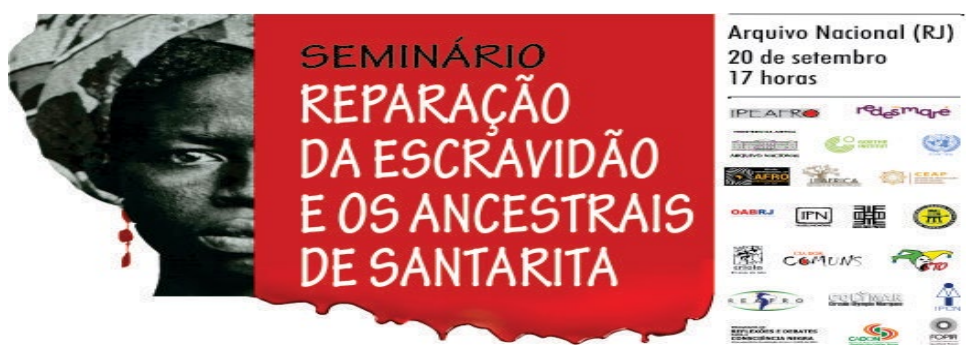

http://ipeafro.org.br/seminario-de-santa-rita-e-os-ancestrais-de-santa-rita/

O objetivo do seminário foi abordar o que ocorre nesse "patrimônio do mundo, que é o Cais do Valongo, e agora com Santa Rita e com a Comissão Pequena África, acompanhar o que acontece nessas intervenções urbanas por cima das ossadas de tanta gente que construiu esse país", conforme afirmou Elisa Larkin, diretora presidente do Ipeafro.

$20 \mathrm{MPF}$ debate futuro do Cais do Valongo (RJ) e da preservação da memória da cultura negra no Brasil. Disponível em: <http://www.mpf.mp.br/rj/sala-de-imprensa/noticias-rj/mpf-debate-futuro-docais-do-valongo-e-da-preservacao-da-memoria-da-cultura-negra-no-brasil>. Acesso em: 03 jan.2019. 
Naquela mesma noite, Negrogun, um componente da mesa, apresentou uma saudação aos orixás, pediu bênçãos aos ancestrais e aos idosos, aos voduns, inquices e orixás- isso pode ser considerado parte da etiqueta ritualística das religiões afro-brasileiras (Segato, 2009). Em sua fala, ele observou que o Cedine, órgão do qual é presidente, se propôs a reunir organizações do movimento negro e discutir e agir diante da intervenção urbana e sua implicação no entorno da igreja. Assim, expôs o que orientou o posicionamento diante das empresas envolvidas com a revitalização e com a atividade arqueológica. Segundo ele, a Comissão Pequena África reivindicava a paralisação das escavações que aconteciam para a instalação do mecanismo de transporte.

A interrupção das obras foi considerada necessária, o que acabou acontecendo, para que ocorresse a negociação entre as empresas, órgãos estatais e as organizações negras. Segundo o expositor, a outra posição foi a de que não houvesse mais escavação e também a "retirada dos ossos dos nossos ancestrais". Sobre isso, continuou:

Nós não somos contra o progresso, em momento algum. Mas não somos a favor e não vamos deixar a destruição da nossa memória. Não vamos deixar a violação de nossos ancestrais, daquele espaço sagrado. Sabemos nós que foram enterrados ali, em liturgias diferentes, sabemos que muitos ali foram enterrados dentro do preceito judaico-cristão, outros foram enterrados ali dentro do preceito muçulmano e outros dentro das tradições dos povos tradicionais de matrizes que ali chegaram e foram enterrados. Mas o ponto básico é que nós não queríamos a escavação, mas exigíamos a demarcação. No início: não, não tem como ter a demarcação se não tiver escavação. O problema não é nosso! ... E hoje, como está a história? Nós não tínhamos como impedir a passagem do VLT e não era o nosso interesse impedir. O que nós queríamos era um compromisso do VLT, do Iphan, da Cdurp e da Prefeitura da Cidade do Rio de Janeiro com a nossa memória e com a reparação.

O foco da Comissão Pequena África junto aos órgãos e empresas implicados com a instalação do $\mathrm{VLT}^{21}$ era a preservação de

21 O VLT tem integrado o sistema de mobilidade urbano e sua instalação no centro da cidade do Rio de Janeiro. Teve início, em 2012, a partir da parceria público-privada e está orçada em 1,2 bilhão de reais. A obra é conduzida por um consórcio de empresas: Grupo CCR (CIIS - Companhia 
Com "os nossos ancestrais": luta e gramática no reconhecimento de lugar de remanescentes humanos no Rio de Janeiro

algo que já se considerava constituir a memória de um segmento da população. No entanto, havia as práticas, as técnicas e as concepções dos especialistas que atuavam na localidade.

No vídeo Comissão Pequena África, produzido pelo Instituto do Patrimônio Histórico e Artístico Nacional (Iphan) e disponibilizado pelo Conselho Estadual da Defesa do Negro (Cedine) em sua rede social, há a manifestação de Maria Dulce Gaspar, coordenadora do Projeto de Arqueologia da empresa Artefato, contratada pelo consórcio de empresas para conduzir a pesquisa arqueológica na área. A especialista explicita que a Comissão Pequena África deixou evidente que não queria intervenção no subsolo, nem que o material ósseo fosse retirado. Diante disso, houve a alteração do procedimento a ser adotado para a instalação do VLT. Sobre isso, ela explica:

Nós já sabíamos como as camadas arqueológicas se comportavam. Nós sabíamos que parte dos esqueletos encontrados estavam a 50, $60 \mathrm{~cm}$ abaixo do nível atual. Em uma conversa técnica com a VLT, percebemos que seria possível passar o VLT sem que fosse na área do cemitério. As tubulações que eram pra passar a $60 \mathrm{~cm}$ foram distribuídas numa área de $30 \mathrm{~cm}$. Eu acho que se nós tivéssemos escavado, nós talvez tivéssemos indícios de fazer algumas associações, mas este grupo de trabalho optou por não fazer esse tipo de investigação, optou pela preservação para manter aquele espaço sagrado. Foi uma opção. Como toda opção tem lados positivos e lados negativos, mas, nesse momento, foi isso que nós todos decidimos fazer.

A imposição das organizações negras em resguardar o local e os restos esqueletais encontrados foi algo que, para os especialistas, afetou a delimitação da área, bem como a atuação do Instituto do Patrimônio Histórico e Artístico Nacional (Iphan), como gestor de bem patrimonial no país. Segundo Maria Dulce Gaspar, esse teve limitação em sua atuação de obter "a materialidade necessária para que possamos dizer com certeza: aqui é o cemitério dos primeiros africanos que chegaram a essa terra". Isso evidencia o entendimento

de Investimentos em Infraestrutura e Serviços 50,39\%), Invepar (20,73\%), Riopar Participações $(14,72 \%)$, Odebrecht Mobilidade $(13,94 \%)$, a BRt - Benito Roggio Transporte $(0,18 \%)$ e a RATP do Brasil Operações - Participações e Prestações de Serviços para Transporte (0,01\%). Disponível em: https://www.vltrio.com.br/\#/transparencia. Acesso em: 14 jan. 2019. 
da contribuição da atividade arqueológica para o patrimônio, sobretudo por externar vestígios materiais da presença e ação humanas, capazes de provocarem emoções e forças, de modo a evocarem memórias e identidades (Gaspar et al, 2017).

A posição da Comissão Pequena África estabeleceu um contraponto em relação à salvaguarda de remanescentes humanos relacionados com a diáspora africana, sobretudo porque a atuação especializada tem corroborado um conhecimento acerca da origem, hábito alimentar dos escravizados, assim como dos modos de tratamento aos quais foram submetidos (Ferreira, 2009). A justificativa para estabelecer outro tratamento estava bem ressaltada na convocação por rede social para a reunião, em junho de 2018, das organizações negras com o consórcio da VLT, realizada no auditório da Companhia de Desenvolvimento Urbano da Região do Porto do Rio de Janeiro (Cdurp). O texto afirmava a importância da participação para o alcance da "preservação da memória através do território histórico, resguardando características inerentes à preservação de campo santo como forma de reparação aos povos que foram escravizados".

Além da não remoção dos remanescentes humanos encontrados, as organizações negras estabeleceram algumas propostas, e uma delas estava relacionada com os nomes a serem dados às estações do VLT. Sobre isso, Negrogun afirmou:

a estação que eles propuseram ser Duque de Caxias, a nossa proposta é que ela passe a ser João Cândido. A estação que seria Camerino, a nossa proposta é que ela volte ao nome original: Valongo. A estação do Largo de Santa Rita, a nossa proposta que seja a estação Caminho das Rosas Negras.

De acordo com o expositor, esse nome estaria associado com a ação de mulheres negras, que, com seu trabalho na localidade, adquiriam a alforria de escravizados. A rosa negra seria utilizada por elas, que integravam uma irmandade religiosa, e sua presença na região se fazia notar de modo específico porque, afirmou:

lembramos que Santa Rita e Santa Terezinha lá elas têm rosas ne- 
Com "os nossos ancestrais": luta e gramática no reconhecimento de lugar de remanescentes humanos no Rio de Janeiro

gras em seus colos. Eu não sabia, agora eu entendo que essas rosas negras nessas santas europeias é uma intervenção da nossa irmandade das rosas negras ali. Ali é o sinal delas. Então, recobrando essa memória, a resistência da mulher negra ao patriarcal, esses anos todos de resistência, não podemos deixar de marcar um nome de uma mulher negra, mas de todas as mulheres negras, de toda a nossa pátria, de toda a nossa africanidade.

O encontro de remanescentes humanos no Largo de Santa Rita não é um caso isolado na cidade do Rio de Janeiro, como comprova a descoberta, em 1996, do Cemitério dos Pretos Novos, próximo ao Cais do Valongo, em decorrência da reforma de residência de uma família. Pode-se acrescentar que próximo da citada igreja se encontra o prédio do Tribunal Regional Federal da $2^{\mathrm{a}}$ região (TRF 2), que atende aos estados do Rio de Janeiro e do Espírito Santo. Afirma-se que, nessa localidade, houve a descoberta e a extração de remanescentes humanos e de artefatos, por ocasião de obras realizadas nos idos dos anos 1990, e que a edificação teria sido construída num terreno que outrora seria alcançado pelo cemitério de Santa Rita. Conta-se ainda que o prédio seria, então, assombrado por fantasmas de escravizados, mas nada disso foi comprovado.

Recentemente, esse prédio foi o centro de uma atividade voltada ao "reconhecimento dos vestígios de ancestrais na região da Pequena África", como parte do seminário sobre políticas públicas e decreto 4.887/03, que trata da demarcação das terras ocupadas por remanescentes das comunidades de quilombos. 


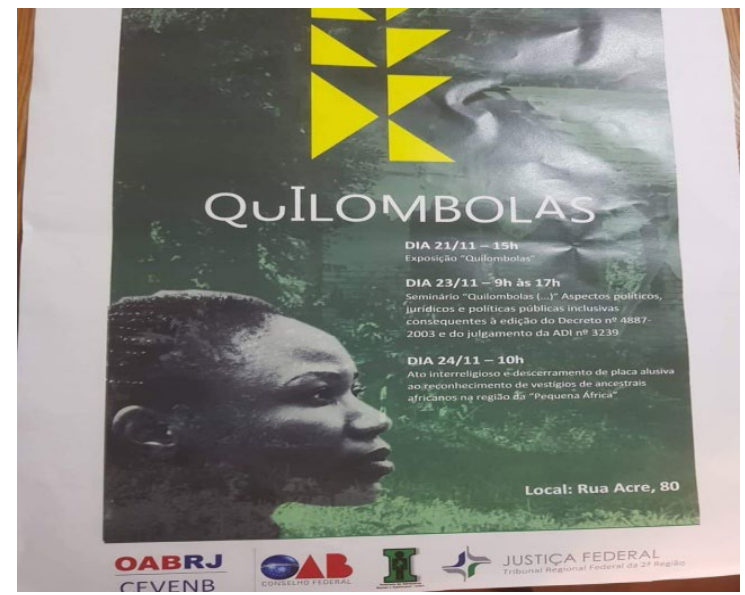

Como parte da programação, num sábado do mês de novembro, foi realizado um cortejo, integrado por representante do judaísmo, do evangelismo, sacerdotes, sacerdotisas e membros das religiões afro-brasileiras, que ostentavam vestes típicas e guias (colares de conta), indicadores da filiação espiritual. Também estavam presentes membros da Comissão da Verdade da Escravidão Negra (Cvenb), grupos de capoeira e componentes da Associação Recreativa Cultural Afoxé Filhos de Gandhi, criada em 1951, cuja sede fica perto do Cais do Valongo, tem atuado em diversas iniciativas na região portuária ligadas com a cultura afro-brasileira.

O grupo iniciou sua caminhada defronte do Museu de Arte do Rio (MAR), inaugurado em 2013, e seguiu em silêncio pelas ruas até o prédio do Tribunal Regional Federal da $2^{\mathrm{a}}$ região (TRF 2), que é vizinho do Largo de Santa Rita e do MAR. Seus componentes levavam palmas brancas e foram recebidos pelo desembargador André Fontes, presidente do tribunal, acompanhado por Humberto Adami, presidente da Comissão Nacional da Verdade da Escravidão Negra no Brasil (Cvenb). No vídeo Cortejo do MAR/TRF2, realizado pela TV Feitiço - ligada à Escola de Samba Feitiço do Rio -, pode ser observado que a comitiva foi se acomodando no saguão da edificação e houve a abertura da cerimônia, realizada pelo presidente do tribunal. Ele afirmou ser a casa um espaço 
Com "os nossos ancestrais": luta e gramática no reconhecimento de lugar de remanescentes humanos no Rio de Janeiro

de "justiça e do povo, mesmo aqueles que um dia sequer foram reconhecidos como pessoas, que durante, talvez mais de 350 anos, estejam aqui nesta área soterrados pela atual civilização". Naquele momento, acontecia, então, um ato de "reconhecimento e respeito" pelos escravizados, daqueles que "estão debaixo da terra em permanente sofrimento, esquecimento e anonimato". Durante a sua fala, afirmou não ter formação religiosa, e sim sentimentos, como o dos demais presentes, no tocante à dignidade dos escravizados. Também enfatizou reconhecer a presença e a importância de expressões religiosas que antes estiveram ausentes no tribunal, bem como a lembrança e o respeito devido àquelas pessoas ali enterradas. Muitas vozes se levantaram dizendo axé - termo comum nas religiões de matrizes africanas que significa força/energia - e repetiram no decorrer de outros discursos que ali aconteceram.

$\mathrm{O}$ advogado Humberto Adami, presidente da Cvenb, foi enfático ao afirmar que aquele momento configurava o "resgate da verdade da história da escravidão negra" e o cumprimento da Constituição Federal. Isso se daria com a abertura do tribunal aos "brasileiros das religiões de matrizes africanas".

Após as falas do desembargador e do advogado, aconteceu o descerramento da placa, que diz:

O prédio onde se encontra a sede do Tribunal Regional Federal da $2^{\mathrm{a}}$ Região integra a região do Centro da cidade conhecida como 'Pequena África' (Praça Mauá e adjacências), onde, por séculos aportaram navios negreiros. A Corte realiza o singelo preito às pessoas oriundas da África e busca trazer a lume o resgate da História do Brasil no período da escravização.

Em seguida, com a emissão de axé pelos presentes, o toque do Filhos de Gandhi, que cooperou com a dimensão sonora e religiosa, um casal paramentado com roupas da religiosidade afro-brasileira se dirigiu à porta de saída do prédio e liberou pombas brancas, ato acompanhado por recitação de palavras de cunho ritual. Depois disso, um grupo de mulheres ficou na entrada da edificação, algumas dançando, outras soltando bolas brancas, e uma outra com uma quartinha branca - recipiente utilizado nos rituais afro-brasileiros 
-, contendo palmas da mesma cor - aspergiu água na portaria da edificação como parte do ritual de lavagem do local.

O homem que libertou a ave branca possui o título de ojé - um sacerdote do candomblé dedicado ao culto dos eguns (ancestrais). Trata-se de ojé Braga, do terreiro Ilê Igbo Agan, integrante de uma família de sacerdotes do candomblé, que definiu da seguinte maneira o que realizou naquele dia: "O que fiz aqui foi uma cerimônia de pacificação dos espíritos das nossas irmãs e irmãos que morreram nos navios negreiros ou que permaneceram escravizados" 22 .

Em entrevista, iyá Regina, integrante do Filhos de Gandhi ${ }^{23}$, observou que a cerimônia seria uma "forma de juntar o povo que lida com a ancestralidade, que reconhece a ancestralidade, para chegar até lá, buscando o maior número de pessoas possível para acalentar a dor daqueles que se foram". Segundo ela, o ato e a placa visam a demarcar que, no local, havia um "campo santo, continuará sempre sendo um campo santo", no qual foram enterrados escravizados e pessoas mortas tragicamente. Portanto, a cerimônia visava a reunir:

as energias de todas as religiosidades, para que os antepassados possam ouvir o nosso clamor de desculpa, o nosso clamor de acalanto. Esse é o nosso clamor. Esse cortejo, todo esse aparato é para que todos possam reconhecer que nunca deverá fazer isso outra vez. Houve o fato, é inegável, mas não podemos retroceder no tempo, mas podemos consertar no futuro essa dor deixada para trás.

Cabe dizer que a cerimônia contou com a participação de representantes de outros credos, tendo alguns discursado brevemente, e compuseram a atmosfera de respeito e fazimento do descanso aos escravizados outrora sepultados naquela região.

Ainda em 2018, as ações para a instalação do VLT foram retomadas e, no curso das obras, não houve a retirada dos remanescentes humanos encontrados. Foi acertado que as estações fariam referências à presença negra na região. Como exemplo, as estações foco das

22 Ato inter-religioso conclui o evento "Quilombolas" no TRF2. Disponível em: $<$ https://www.jfrj. jus.br/noticia/ato-inter-religioso-conclui-o-evento-quilombolas-no-trf2>. Acesso em: 12 mar. 2019.

23 Disponível em https://www.youtube.com/watch?v=TphUV1vsR8w. Acesso em: 13 mar. 2019. 
Com "os nossos ancestrais": luta e gramática no reconhecimento de lugar de remanescentes humanos no Rio de Janeiro

discussões passaram a ser chamadas Cristiano Otoni/Pequena África, Camerino/Rosas Negras, Santa Rita/Pretos Novos. Além disso, os trens receberão os nomes de três mães de santo, sendo escolhidas pela luta que tiveram em defesa das religiões afro-brasileiras, dos direitos humanos, combate ao sexismo, ao racismo e respeito ao matriarcado.

\section{CONCLUSÃO}

Foi apontado que, na região portuária, tem ocorrido conflitos, negociações e mobilizações de moradores e movimentos sociais para confrontar a lógica da revitalização urbana, que altera o antigo centro da cidade, buscando preservar e valorizar alguns lugares. Nesse caso, organizações do movimento negro enfatizam aqueles que contam a história da presença e contribuição de escravizados e de negros livres para a cidade e para o país. Isso inclui diversos locais, sendo citado aqueles ligados com a articulação e a circulação de lideranças religiosas envolvidas com o fortalecimento e a resistência das religiões afro-brasileiras.

Foi evidenciado que a carta em nome da Comissão Pequena África visou a reivindicar, para o Largo de Santa Rita, outro estatuto, por representar as práticas desumanas - também consideradas danosas para o presente -, sobretudo com o volume de africanos e negros cativos, mortos e sepultados no antigo cemitério, assim como as ações por liberdade. O local tem sido, então, equiparado com o Cais do Valongo, onde acontecia o desembarque de escravizados. Também tem sido visto como equivalente a outros lugares marcados por acontecimentos traumáticos e eliminação de vidas humanas como os campos de concentração. Nessa perspectiva, a referência ao holocausto judeu tem sido recorrente no cenário pesquisado, que visualiza sua convergência com a escravidão, entendida também como uma empreitada racional e voltada à submissão e eliminação de vidas humanas, mas diferente, porque a população negra ainda não foi compensada pelos danos.

Apontei a interação entre os diferentes atores que lidaram com o tema dos remanescentes humanos no Largo de Santa Rita, sobressaindo a tensão entre as organizações negras e os especia- 
listas que faziam o estudo arqueológico. Os profissionais visavam a resgatar os remanescentes ósseos, intervir no subsolo para obter mais vestígios materiais das práticas e condições de sepultamento e demarcar a área do cemitério. Algo em nada estranho ao contexto dessa especialização (Gaspar et al, 2017; Lessa; Tavares; Carvalho, 2018), que tem sua atuação também legitimada pelos estudos sobre a diáspora africana e a escravidão - vida comunitária e modos de resistência (Ferreira, 2009).

Convém destacar que o fazer especializado de investigação de fossas mortuárias e exumação de corpos tem sido aplicado alhures para enfrentar as situações de violência política. Em contexto de conflitos políticos, a exumação, para muitos, pode ser considerada um ato de reparação ou de justiça histórica com os mortos (Ferrandiz, 2017; Rousseau, 2017).

As associações negras da Comissão Pequena África, ambientadas com o vocabulário do dispositivo de esclarecimento histórico, posicionaram-se contra o resgate dos remanescentes humanos que seria realizado pela arqueologia. Para tanto, argumentaram que resistiam à profanação/violação dos antepassados que, para eles, repousavam no que entendem ter sido um campo santo. Assim, ambos, o local e os remanescentes humanos, deveriam ser preservados, sobretudo porque acreditam que os sepultamentos ocorreram com algum ritual religioso. No entanto, a literatura especializada aponta para a prática de sepultamento coletivo dos escravizados e consequente apagamento de seus referenciais culturais (Pereira, 2007; Nara Jr, 2014). No local, estão os ossos daqueles considerados ancestrais, condição daquela/e que, por feitos na existência terrena, passou a fazer parte da memória da comunidade (Pinheiro; Carneiro, 2016). A resistência a sua retirada pode ser considerada um modo de resguardá-los, pois os ossos talvez não fossem reenterrados porque direcionados a usos e locais incertos ${ }^{24} \mathrm{e}$, assim, não chegariam à condição de artefato arqueológico ou de musealização, condições que também não interessavam aos envolvidos. Portanto, a não remoção dos remanescentes humanos indica a cautela no tocante à possibili-

24 Nesse sentido, perdura o descontentamento com a indefinição dada ao material recolhido no Cais do Valongo, posto que armazenado em contêineres. 
dade da perda da aura, assegurada com a separação de algo, de não ser acessado/utilizado ordinariamente (Agamben, 2007).

Então, considerando o que foi apresentado, pesou menos o interesse em retirar os ossos para garantir a materialidade do bem patrimonial a ser administrado pelo Estado, conforme prevê a legislação federal do Instituto de Patrimônio e Artistico Nacional (Iphan), que trata da gestão de patrimônio. O posicionamento da Comissão Pequena África foi adensado com a articulação que compreendeu, de um lado, a permanência dos vestígios humanos no local. Isso seria um ato de respeito, de referência e cuidado, e, de outro, de reparação, pois também incluiria a preservação da memória afro-brasileira. Essa questão também compreendeu a garantia por parte das empresas e dos órgãos públicos envolvidos com as obras de revitalização o cumprimento de outras exigências, tais como: o nomes das estações e dos trens do VLT, piso diferenciado para demarcar a luta das mulheres negras, projeto de educação patrimonial a ser desenvolvido nas escolas da região e tudo isso passa a ser visível nas ruas da cidade.

Outra dimensão evidenciada tem a ver com a ligação com a religião, podendo ser apontada a ênfase dada às ações de liberdade empreendidas por mulheres numa confraria identificada por rosas negras, cuja presença e atuação estariam codificadas na ornamentação das imagens de algumas santas, principalmente, àquela ligada aos casos de difícil solução. Esse tema é valioso no cenário pesquisado, porque tem a ver com a importância das irmandades religiosas, com atuação no Rio de Janeiro a partir de 1639, envolvidas com a oferta de apoio espiritual, material e cuidados relacionados com a morte funeral, sepultura e missa -, que assegurariam a sua dignidade. Essas irmandades religiosas se faziam presentes na paisagem urbana e conduziam táticas para a obtenção da almejada liberdade e ultrapassagem do escravismo (Reginaldo, 2018). O tema da atuação das mulheres negras por liberdade tem sido aproximado dessas atuações das irmandades, assim como dos feitos das santas populares (Giumbelli; Tavares, 2015), sobretudo de Santa Rita - reconhecida como a intercessora dos casos impossíveis e desesperados - porque a dedicação feminina possibilitaria alcançar a liberdade, algo quase impossível.

A agência das organizações do movimento negro ficou eviden- 
te com as interações com atores de outras instâncias, que teve diferentes momentos aqui descritos - desde a leitura da carta no encontro do Ministério Público Federal, as exigências colocadas para as empresas e órgãos públicos implicados com a revitalização da zona portuária até as manifestações do dirigente do Tribunal Regional Federal da $2^{\mathrm{a}}$ Região (TRF2) e do presidente da Comissão da Verdade da Escravidão Negra no Brasil (Cvenb). As situações explicitaram a mobilização dos coletivos negros e a cooperação da religião para a elaboração de espaço de manifestação ancorada na exigência de "recursos e direitos" (Segato, 2009, p.51). Ainda problematizaram o tema do acesso desigual dessas religiões ao espaço público, pois, em geral, as religiões afro-brasileiras estão presentes nas periferias das cidades e do campo religioso brasileiro (Miranda, 2019).

As interações apontadas possibilitaram que uma ekedi fizesse uma saudação a Xangô, orixá também relacionado com a Pedra do Sal, localizada na região portuária, de modo a finalizar a reunião convocada por procuradores do Ministério Público Federal; um participante também realizou a saudação aos orixás e aos ancestrais no seminário sobre reparação e escravidão realizado do prédio do Arquivo Nacional, onde ainda ocorreu a referência a Exú - entidade que rege a dimensão da comunicação. Por fim, aconteceu a cerimônia religiosa nas dependências do prédio do Tribunal Regional Federal da $2^{\mathrm{a}}$ Região (TRF2). Tais momentos têm a ver com as potencialidades da religião na arena pública e isso envolve a criação de um espaço sagrado - fortemente referido à força dos ancestrais -, sua imbricação com a diversidade cultural e com as alterações urbanas (Giumbelli; Tavares, 2015).

Demonstrei como alguns remanescentes humanos impulsionaram diversas interações e aplicação de vocábulos que adensaram a manifestação religiosa e a reivindicação de reparação da escravidão. Um momento exemplar pode ser o culto no qual aves foram ofertadas e soltas, flores e água utilizadas para lavar ritualmente o chão, cantos e danças dedicados aos ancestrais. Por sua vez, os agentes religiosos contribuíram para reafirmar os escravizados como vítimas e o local como testemunho das violações praticadas no passado. Também houve disposição em proporcionar a pacificação dos espíritos, realizando-se o clamor de desculpas, para acalentar a dor daqueles que tiveram 
Com "os nossos ancestrais": luta e gramática no reconhecimento de lugar de remanescentes humanos no Rio de Janeiro

morte trágica, quando trazidos do continente africano para o país. Igualmente, falou-se em axé, perdão e ancestralidade, expressões comuns à linguagem religiosa, e as cerimônias foram apresentadas como necessárias, porque a morte física não foi capaz de findar o sofrimento. Então, as cerimônias e o vocabulário apresentado possibilitam, de um lado, demarcar os danos impostos aos escravizados e, de outro, eles têm a ver com a gestão da espiritualidade e do sobrenatural, que as religiões afro-brasileiras procuraram conduzir (Segato, 2009).

Ativistas e especialistas em direito têm visado instalar e consolidar um esclarecimento histórico sobre a escravidão no país, recorrendo a específica gramática: reparação, verdade, história, memória, resistência, reconhecimento, justiça, dignidade e respeito. Por sua vez, os vocábulos e as expressões proferidos por religiosos foram relevantes para a versão local de esclarecimento histórico, que resultou em conquistas. Como foi apontado, as estações do mecanismo de transporte fazem menção aos escravizados enterrados, os trens do VLT homenageiam lideranças das religiões afro-brasileiras, o Tribunal Regional Federal da 2a Região inaugurou uma placa de reconhecimento aos escravizados desembarcados na região portuária. Esses são alguns dos acontecimentos que evidenciam o que os mortos podem impulsionar, pois, em certas configurações, eles podem adquirir potencialidade política (Rousseau, 2017).

Não há como ignorar que as atividades e as interações discursivas (Montero, 2012) se mostraram eficientes para tecer os escravizados como vítimas merecedoras do culto e das homenagens que sucederam, corroborando um espaço religioso e, ao mesmo tempo, um lugar de reflexão sobre as violações praticadas no passado (Reategui, 2010). Esse espaço tem a ver com o encontro e a negociação entre opostos, isto é, entre o institucionalizado e as criações culturais, o local e o global que se relacionaram e se constituíram (De La Torre, 2012). Para tanto, o lugar material e os ossos humanos apareceram como relevantes atores e merecedores de defesa, especialmente porque as falas, as práticas e as relações corroboraram seu reconhecimento como sinais do passado que devem marcar a paisagem urbana (Flores, 2009). 


\section{REFERÊNCIAS}

AGAMBEM, Giorgio. Profanações. São Paulo: Boitempo, 2007.

BARROS, J. F. P. de. O banquete do rei... Olubajé: uma introdução à música sacra afro-brasileira. Rio de Janeiro: Ao Livro Técnico, 2000.

BRASIL. Lei no 12. 528. In: Diário Oficial da União, Brasília, 18 novembro de 2011.

. Decreto 4.887. In: Diário Oficial da União, Brasília, 21 novembro de 2003.

- Constituição da República Federativa do Brasil. Publicado no Diário Oficial da União - 191-A - 05 out.1988, p. 1.

CARNEIRO, S; PINHEIRO, M. Cais do Valongo: patrimonialização de locais, objetos e herança africana. Religião e Sociedade, vol. 35, $\mathrm{n}^{\mathrm{o}} .2, \mathrm{pp} .384-401,2015$.

CASTILLEJO, A. La imaginación social del porvenir: reflexiones sobre Colombia y el prospecto de una Comisión de la Verdad. Buenos Aires: Clacso,

. Entrevista con Alejandro Castillejo: hablando del otro desde el propio otro o la alteridad como una construcción social. Ankulegi, nº.17, pp.89-106, 2013. Entrevista concedida à Adriana Villalón.

CONDURU, R. Das casas às roças: comunidades de candomblé no Rio de Janeiro desde o fim do século XIX. Topoi, vol. 11, nº 21, pp. 178203, 2010.

CUYA, Esteban. Justiça de Transição. Acervo, vol. 24, nº.01, pp.37-78, 2011.

DE LA TORRE, R. La religiosidad popular como "entre-medio" entre la religión institucional y la espiritualidad individualizada. Civitas, vol. 12, no. 3, pp. 506-521, 2012.

FASSIN, D. La economía moral del asilo. Reflexiones críticas sobre la «crisis de los refugiados» de 2015 en Europa. Revista de Dialectología y Tradiciones Populares, vol. LXX, nº. 2, pp. 277-290, 2015.

FERRANDIZ, F. Entre víctimas: investigando las exhumaciones de las fosas comunes de la Guerra Civil en la España contemporânea. In: GATTI, G. Un mundo de víctimas. Barcelona: Anthropos Editorial, 2017. pp.209-219.

FERREIRA, Y. Entrevista. In: ALBERTI, V.; PEREIRA, A. A. (Orgs.). Histórias do movimento negro no Brasil: depoimentos ao Cpdoc. 
Com "os nossos ancestrais": luta e gramática no reconhecimento de lugar de remanescentes humanos no Rio de Janeiro

Rio de Janeiro: Pallas; CPDOC-FGV, 2007. pp.413-417.

FERREIRA, L.M. Sobre o conceito de arqueologia da diáspora. MÉTIS: história \& cultura vol. 8, nº. 16, pp. 267-275, 2009.

FLORES, F.C. Un lugar en el mundo. Procesos de construcción de lugares religiosos desde la perspectiva de una villa adventista (Puiggari, Entre Ríos). XII ${ }^{\circ}$ Encuentro de Geógrafos de América Latina, Montevideo, 2009.

GASPAR, M.D.; et al. Patrimônio arqueológico e a renovação do centro da cidade do Rio de Janeiro. In: CAMPOS, G; GRANATO, M. (Orgs.). Preservação do patrimônio arqueológico: desafios e estudos de caso. Rio de Janeiro: Museu de Astronomia e Ciências Afins, 2017. pp.03-22.

GATTI, G. Un mundo de víctimas. Barcelona: Anthropos Editorial, 2017.

GIUMBELLI, E.; TAVARES, F. Introdução - religiões e temas de pesquisa contemporâneos. In: . (Orgs.). Religiões e temas de pesquisa contemporâneos: diálogos contemporâneos. Salvador: Edufba, 2015. pp.9-32.

GIUMBELLI, E. O que é um ambiente laico? Espaços (inter)religiosos em instituições públicas. Cultura y Religión, vol. 7, nº. 2, 2013, pp. 32-47.

GUIMARÃES, R. A utopia da Pequena África: projetos urbanísticos, patrimônios e conflitos na Zona Portuária carioca. Rio de Janeiro: Editora FGV, 2014.

HAYNER, P. B. Truth commissions: a schematic overview. International Review of the Red Cross, vol. 88, nº. 862, pp. 295-310, 2006.

HONORATO, C. de P. Valongo: o mercado de escravos do Rio de Janeiro, 1758-1831. 2008. Dissertação (Mestrado em História) - Universidade Federal Fluminense, Programa de Pós-Graduação em História, Niterói, 2008.

IPHAN. Sítio arqueológico Cais do Valongo - proposta de inscrição na lista de patrimônio mundial. RJ, 2016.

LAO-MONTES, A. Cartografías del campo político afrodescendiente en América Latina. Universitas Humanística, nº. 68, pp. 207-245, 2009. Disponível em: https://revistas.javeriana.edu.co/index.php/ univhumanistica/article/view/2273/1579. Acesso em: 19 set.2018.

. Sin Justicia étnico-racial no hay paz: las afro-reparaciones en perspectiva histórico-mundial. In: MOSQUERA, C.; BARCELOS, L. C. (Orgs.). Afro-reparaciones: memorias de la esclavitud y justicia reparativa para negros, afrocolombianos e raizales. Bogotá: 
Universidad Nacional de Colombia, 2007. pp.132-153.

LEITÃO, L.R. S.; SILVA, M. K. Institucionalização e contestação: as lutas do movimento negro (1970-1980). Politica e Sociedade, vol. 16, nº. 37, 2017.

LESSA, A.; TAVARES, R.B.; CARVALHO, C.R. Paisagem, morte e controle social: o Valongo e o cemitério dos pretos novos no contexto escravocrata do Rio de Janeiro nos séculos XVIII e XIX. Revista Paisagens Hibridas, vol.1, nº.1, pp.132-161, 2018.

Mattos, H.; Abreu, M.; Guran, M. Inventário dos lugares de memória do tráfico atlântico de escravos e da história dos africanos escravizados no Brasil. Niterói: PPGH-UFF, 2014.

MIRANDA, A.P.M. Se está nos autos, está no mundo: a intolerância religiosa e os limites de aceitação de identidades públicas. In: MIRANDA; A.P.M. MOTA, F.R.; PIRES, L. (Orgs.). As crenças na igualdade. Rio de Janeiro: Autografia, 2019. pp.29-67.

MONTERO, P. Controvérsias religiosas e esfera pública: repensando as religiões como discurso. Religião e Sociedade, vol.32, nº.1, pp.167183, 2012.

NARA JR. J. C. O pioneirismo da Matriz de Santa Rita de Cássia no Rio de Janeiro no panorama da arquitetura religiosa colonial brasileira. In: SIMPÓSIO NACIONAL DA ABHR, 14., Juiz de Fora, 2015. Anais... Juiz de Fora, ABHR, 2015. Vol. 14, pp.719-728. Disponível em: http://www.abhr.org.br/plura/ojs/index.php/anais/article/view/928. Acesso em: 15 out. 2018.

OAB/RJ. 2015. Relatório da Comissão Estadual da Verdade da escravidão negra. Rio de Janeiro: OAB/RJ.

PEREIRA, J. C. M. da S. À flor da terra: o cemitério dos pretos novos no Rio de Janeiro. Rio de Janeiro: Garamond; IPHAN, 2007.

PINHEIRO, M. "The sound of silenced voices": mobilizations, connections and demands in the investigation of slavery in Brazil. Vibrant, Virtual Braz. Anthr. vol.15, no.3, 2018a.

PINHEIRO, M. Uma Comissão da Verdade no Brasil: escravidão, multiculturalismo, história e memória. Civitas, vol. 18, nº. 3, pp. 683-698, 2018b.

PINHEIRO, M.; CARNEIRO, S. Revitalização urbana, patrimônio e memórias no Rio de Janeiro: usos e apropriações do Cais do Valongo. Estudos Históricos, vol. 29, nº. 57, pp. 67-86, 2016.

PCRJ. Decreto No 34.803. In: Diário Oficial do Município do Rio de Janeiro, 
Com "os nossos ancestrais": luta e gramática no reconhecimento de lugar de remanescentes humanos no Rio de Janeiro

Rio de Janeiro, ano 25, no. 117, pp. 1, 30/11/2018.

PCRJ. Lei $n^{\circ} 1370$, de 29 de dezembro de 1988. In: Diário Oficial do Município do Rio de Janeiro em 30/12/1988.

REATEGUI, F. Los sitios de la memoria: procesos sociales de la conmemoración en el Perú. Lima: Pontificia Universidad Católica del Perú, Konrad Adenauer Stiftung, 2010.

REGINALDO, L. Irmandades. In: SCHWARCZ, L.M; GOMES, F.G. (Orgs.) Dicionário da escravidão e liberdade - 50 textos críticos. São Paulo: Companhia das Letras, 2018. pp.268-271.

RODRIGUES, C. Lugares dos mortos na cidade dos vivos: tradições e transformações fúnebres no Rio de Janeiro. Rio de Janeiro: Secretaria Municipal de Cultura; Departamento Geral de Documentação e Informação Cultural; Divisão de Editoração, 1997.

ROUSSEAU, N. Identificación, política, disciplinas: personas desaparecidas y esqueletos coloniales en África del Sur. In: GARIBIAN, S.; ANSTETT, E.; DREYFUS, J.M. Restos humanos y identificaciónviolência de masa, genocídio y el 'giro forense'. Buenos Aires: Miño y Dávila, 2017. pp. 163-190.

SANTOS, V. A. A reparação da escravidão negra no Brasil: fundamentos e propostas. Revista Eletrônica OAB/RJ, vol.29, nº. 2, 2018.

SEGATO, R. La faccionalización de la república y el paisaje religioso como índice de una nueva territorialidade. CLACSO, 2009.

UNESCO. Legados de la esclavitud: una guía para la administración sitios y itinerarios de memoria. Paris: Unesco, 2019.

WIEVIORKA, M. Violence: a new approach. New Delhi: Sage Publications, 2009. 